\title{
Apoptosis-Modulating Drugs for Improved Cancer Therapy
}

\author{
M. Ocker ${ }^{\text {a }}$ M. Höpfner ${ }^{b}$ \\ ${ }^{a}$ Institute for Surgical Research, Philipps University Marburg, Marburg, and ${ }^{\mathrm{b}}$ Institute of Physiology, \\ Charité Universitätsmedizin Berlin, Campus Benjamin Franklin, Berlin, Germany
}

\section{Key Words}

Apoptosis · Autophagy · Endoplasmic reticulum stress •

Unfolded protein response $\cdot$ Necroptosis

\begin{abstract}
Resistance to cell death induction has been recognized as a hallmark of cancer. Increasing understanding of the underlying molecular events regulating different cell death mechanisms like apoptosis, endoplasmic reticulum stress, autophagy, necroptosis and others has opened new possibilities for targeted interference with these pathways. While conventional chemotherapeutic agents usually inhibit cell cycle progression, DNA replication or mitosis execution, novel agents like small molecule kinase inhibitors also target survival-related kinases and signaling pathways and contribute to overcome resistance to chemotherapy and apoptosis. Additionally, antibodies targeting cellular death receptors have been described to specifically target tumor cells only. This review briefly highlights the pathways involved in (apoptotic) cell death and summarizes the current state of development of specific modulators of cell death and how they can help to improve the tolerability of chemotherapy regimens and increase survival rates in patients with advanced cancer diseases.

Copyright ๑ 2012 S. Karger AG, Basel
\end{abstract}

\section{Introduction}

Since its first recognition as a physiologic process of cellular turnover and tissue homeostasis 4 decades ago [1], programmed cell death mechanisms have received increasing attention as central regulators of (patho-)physiologic conditions. The uncontrolled initiation and execution of various cell death programs have been linked to various disease conditions, e.g. transplant rejection, autoimmune diseases or ischemic heart failure. Especially the ability to resist cell death has been identified as a key feature of malignant cells and has therefore been considered a hallmark of cancer [2].

Conventional chemotherapeutic agents like 5-fluorouracil, irinotecan, doxorubicin or platinum derivatives unspecifically interfere with DNA and RNA metabolism and replication during the $S$ phase of the cell cycle, while agents like taxol derivatives arrest cells during mitosis and lead to mitotic catastrophe. Yet, these commonly used and well-established compounds lead to cell death induction only secondarily and show a high rate of resistance development $[3,4]$. The introduction of targeted therapies using small molecule kinase inhibitors like sorafenib, everolimus, imatinib or growth factor-related antibodies like cetuximab or bevacizumab has shown

\section{KARGER}

Fax +4161306 1234

E-Mail karger@karger.ch

www.karger.com (c) 2012 S. Karger AG, Basel

0014-312X/12/0483-0111\$38.00/0

Accessible online at:

www.karger.com/esr
Prof. Dr. med. Matthias Ocker

Institute for Surgical Research, Philipps University Marburg Baldingerstrasse

DE-35043 Marburg (Germany)

Tel. +496421586 8930,E-Mail ocker@staff.uni-marburg.de 
that a direct interference with survival and cell deathrelated signaling pathways can significantly improve patient survival for various cancers [5-9]. Recently, the increasing knowledge about the molecular mechanisms involved in cell death initiation, execution and regulation has opened new possibilities to directly target the cellular cell death machinery in a more specific manner.

We will here briefly review the current concepts of cell death mechanisms in general and of cancer-related alterations with a special focus on novel targeted agents for modern personalized cancer chemotherapy.

\section{Types of Cell Death: Apoptosis, Necroptosis and Autophagy}

Although there is increasing evidence that the three major ways of cell death, apoptosis, necrosis/necroptosis and autophagy, share overlapping molecular features and pathways and can occur also in parallel under the same conditions [10-13], they will be discussed separately here. Mitotic catastrophe represents a fourth way of cell death but will not be discussed here, and we refer to other excellent reviews on this topic $[14,15]$.

\section{Apoptosis}

Apoptosis is considered the classical way of programmed cell death. Morphologically, typical features comprise the condensation and pyknosis of nuclei, the formation of membrane blebbings and the complete consumption of apoptotic cells by phagocytes without an inflammatory response [16-18].

The apoptotic machinery can be activated by various intrinsic and extrinsic stimuli (fig. 1). The extrinsic pathway is activated by binding of specific ligands to so-called death receptors of the tumor necrosis factor (TNF) receptor superfamily at the cellular surface $[19,20]$. Ligand binding to its cognate receptor (FasL-Fas/CD95, TRAILDR4 or DR5, TNF-TNFR1) leads to receptor trimerization and activation of intracellular death domains and recruitment of death domain-containing adapter proteins like Fas-associated death domain or TNF receptorassociated death domain that form a death-induced signaling complex which contains the proform of the initiator caspases 8 or 10 [17, 21, 22]. Extrinsic apoptosis induction is controlled at the level of signal transduction by inhibitory proteins like cellular FLICE-inhibitory protein [23] and at the level of ligand binding by the expression of decoy receptors (DcR1, DcR2 and DcR3) lacking intracellular death domains [24].
Various factors can activate the intrinsic or mitochondria-mediated apoptosis cascade. Among them are hypoxia or ischemia (antiangiogenic therapy), reactive oxygen species production (radiation therapy) or inhibition of growth factor signaling (small molecule kinase inhibitors or antibody therapy) [17]. These intracellular stress signals activate proapoptotic members of the Bcl-2 (B cell lymphoma 2) family $[25,26]$, e.g. the $\mathrm{BH} 3$-only proteins Bad or Bim which in turn inhibit the function of antiapoptotic members of this protein family like Bcl-2, Bcl$\mathrm{xL}$ or Puma/Noxa. This allows Bax and Bak, other proapoptotic members of the Bcl-2 family, to dimerize and translocate to the outer mitochondrial membrane and to trigger the release of proapoptotic mediators like cytochrome $\mathrm{c}, \mathrm{Ca}^{2+}$ or the inhibitors of apoptosis proteins (IAPs) Smac/DIABLO into the cytosol [27-30]. Cytochrome $\mathrm{c}$ then forms a complex with the apoptotic protease-activating factor 1 to build the so-called apoptosome which attracts and cleaves procaspase 9 to activate the caspase cascade [31-33].

Recent findings demonstrate that the Bcl-2 family also affects the integrity of other intracellular membranes and compartments like the endoplasmic reticulum (ER) leading to the release of $\mathrm{Ca}^{2+}$ which activates several intracellular cytotoxicity mechanisms like endonucleases, transglutaminase or proteases [34-38]. Additional factors inducing ER stress-mediated apoptosis include oxidative or chemical damage of the ER membrane and the activation of the unfolded protein response (UPR) [39]. Briefly, misfolded proteins activate signaling pathways like the transcription factor ATF6, which mediates the transcription of UPR target genes including chaperones of the heat shock protein 70 and 90 families (e.g. BiP or GRP94) [40, 41]. Alternatively, ER stress can activate transmembrane proteins located in the ER membrane like IRE1 and PERK [39]. These molecules inhibit general protein synthesis and activate the noncanonical apoptosis response via activation of the stress kinase JNK and subsequently of caspase 12 [42-45].

The execution of apoptotic cell death is mediated by a family of cysteinyl aspartate proteinases (caspases) consisting of at least 14 members. Caspases are synthesized as inactive proforms consisting of a large and a small subunit that upon cleavage of the propeptide form the active enzyme complex [46]. Caspases show a hierarchical organization with several initiator caspases (see below) and the effector caspases 3, 6 and 7 that mediate the typical cleavage of cellular structures during apoptosis execution [47]. Active caspases induce the proteolytic cleavage of numerous cellular proteins $[17,48]$, e.g. apoptosis regula- 


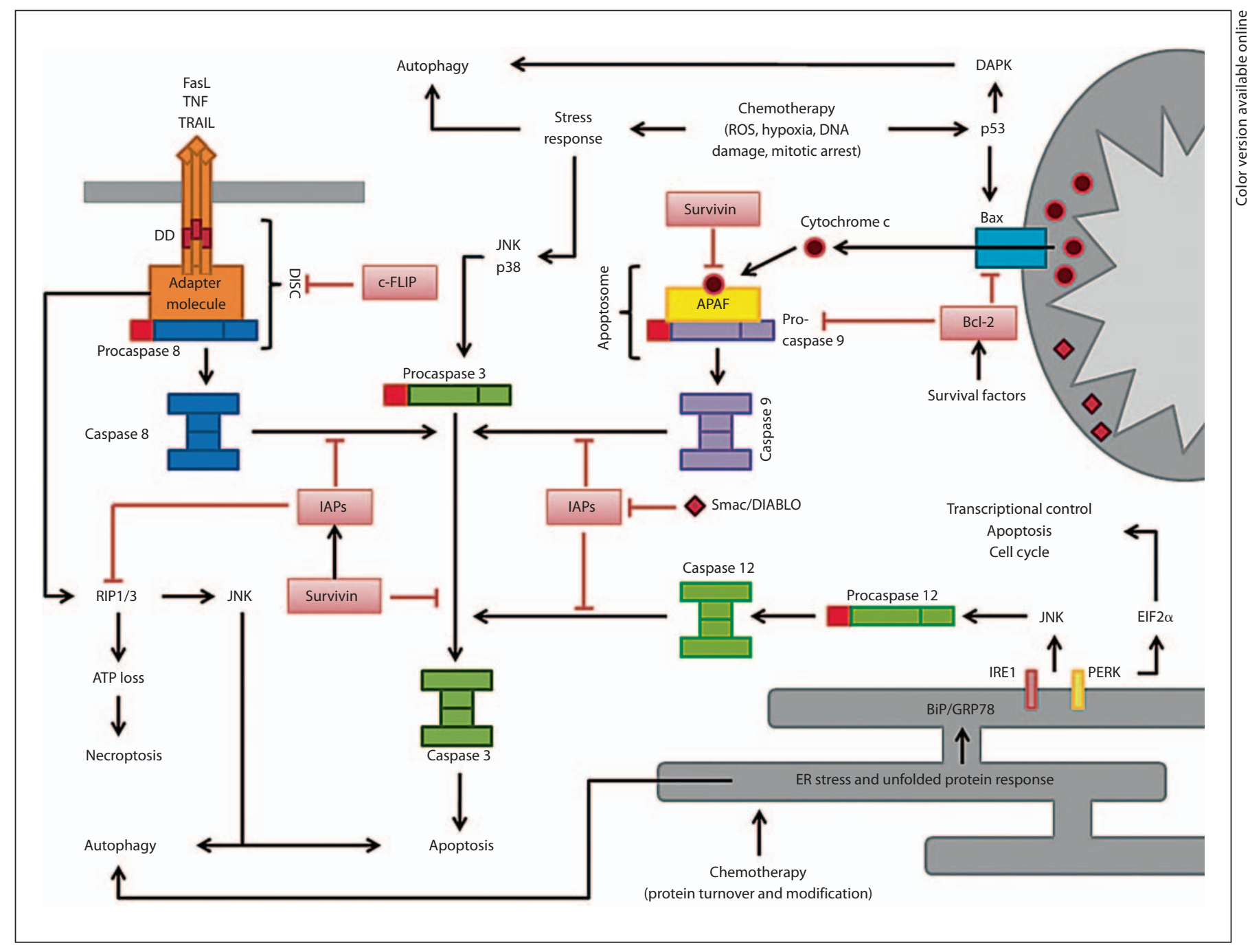

Fig. 1. Schematic representation of cell death pathways. See main text for details.

tors like other caspases or Bcl-2 family members [49, 50], structural proteins like cytokeratins $[51,52]$ or ROCK-1 kinase [53], cell cycle regulators like $\mathrm{Rb}$ [54] or p21 $1^{\text {cip1/waf1 }}$ [55] or DNA-metabolizing enzymes like the caspase-activated DNAse inhibitor [56, 57]. Caspase activity itself is controlled by the IAP family of BIR-domain containing proteins like XIAP, cIAP-1, cIAP-2 or survivin [58-60]. Interestingly, XIAP and cIAP-1 themselves are target molecules for caspases and must be cleaved to execute apoptosis [61]. IAPs also control the death-receptor-mediated induction of necroptosis by inhibiting receptorinteracting proteins (RIPs) associated with necroptotic cell death [62].

\section{Necrosis and Necroptosis}

Necrotic cell death has been characterized as a morphologic distinct form of cellular demise leading to swelling and rupture of organelles and cells due to lack of ATP and breakdown of ion gradients. Unlike apoptosis, this causes an enhanced inflammatory response in affected tissues [17]. Recent data also show a physiologic role for necrosis, e.g. during intestinal cell renewal, and further data also evidence a programmed control and execution of this form of cell death [63-66], which is therefore now called necroptosis [67]. Defects in death receptor signaling and inhibition of caspase 8 activity stabilize the receptor-interacting proteins RIP1 and its homologue RIP3 and activating their kinase domains. RIP1 can translo-

Eur Surg Res 2012;48:111-120 
cate to the mitochondria and rapidly disrupt the ADP/ ATP translocase complex which leads to the typical loss of ATP [68]. Although the exact mechanism of RIP1 activity is still unclear, production of reactive oxygen species, ceramide and interference with stress-related JNK have been proposed and thus provide a crosslink to apoptotic and autophagic cell death pathways, too (fig. 1) [66, 69-70].

\section{Autophagy}

Autophagy has originally been described as a physiologic response to nutrient deprivation and means of cellular survival under stress conditions. Morphologically, autophagy is characterized by the formation of cytoplasmic vacuoles containing cellular organelles or protein aggregates and the absence of typical features of apoptotic cell death. Biochemically, cell death is executed without activation of caspases. Formation of autophagic vacuoles involves several members of the ATG gene family that can recruit the $\mathrm{BH} 3$-domain-containing regulator beclin 1 [71] and the phospoinositide-3-kinase (PI3K) member VPS34. This complex then activates other ATG members that recruit the protein LC3 and conjugate it with phosphatidylethanolamine that finally forms the autophagosome vesicle. The mature autophagosome then fuses with a lysosome to an autophagolysosome leading to the digestion of its content $[72,73]$.

Because of its role in protein turnover and recycling of cellular components, autophagy is also closely linked to ER stress and UPR-induced apoptotic cell death [74]. Yet, it is still under debate, whether autophagy may be a mere cell survival mechanism either antagonizing apoptosis pathways or contributing and enhancing cell death programs under certain conditions like failure of caspase activation or defects in Bax or Bak functions [75-77].

\section{Cell Death Deficiency in Cancer}

Defects in initiating or executing cell death programs are considered a hallmark of malignant cells [2]. This deficiency is responsible for resistance to conventional and targeted chemo- and radiotherapy as well as the limitations of overall survival in cancer patients and the development of metastasis [78]. As cell death deficiency provides a significant advantage for tumor cells, all of the pathways described above can be altered in cancer. Overexpression of antiapoptotic molecules like Bcl-2, Bcl-xL, IAPs or survivin are therefore commonly detected in human cancer and linked to poor prognosis
[79-86]. Consequently, also the loss of proapoptotic factors like death receptors, adapter molecules or caspases has been observed in this context [87-93]. Interestingly, also the commonly observed increased expression or activity of growth-factor signaling cascades (e.g. epidermal or vascular endothelial growth factors) can influence cell death sensitivity by their convergence with mitogen-activated protein kinase or PI3K/Akt signaling. Active Akt provides strong survival signals by phosphorylating and thus inactivating e.g. proapoptotic molecules like Bad or caspase 9 or forkhead transcription factors regulating the expression of e.g. Fas or Bim [94-96]. Downstream, Akt also activates the mammalian target of rapamycin complex, which is considered a master regulator of hypoxia response and autophagy induction [11, 12, 97-99].

\section{Novel Compounds Enhancing Cell Death Responses}

Although most chemotherapeutic agents used today can at least partially induce apoptotic cell death, more specific drugs targeting the pathways described above have recently been developed. As most of the compounds described below are in early clinical trials, no concluding information about the overall efficacy in terms of prolongation of survival time and response rates is so far available.

\section{Death Receptor Pathway}

While the stimulation of the Fas/CD95 system is limited by severe systemic toxicities including acute liver failure, the DR4/DR5 and TNF apoptosis-inducing ligand (TRAIL) system represent promising targets in early phase clinical trials.

Several agonistic and fully human monoclonal antibodies to DR5 have recently been introduced [100]. Conatumab (AMG 655) [101], tigatuzumab (CS-1008) [102], lexatumumab [103] and drozitumab (PRO95780) [104] have been investigated in several phase 1 and phase 2 trials as single agents or in combination with various chemotherapeutic regimens for different solid tumors [105-109]. Mapatumumab represents the only available fully human monoclonal antibody activating DR4 [110114].

Dulanermin is a recombinant human fragment consisting of 167 amino acids of the natural Apo2L/TRAIL ligand and mediated proapoptotic functions by binding to DR4 and DR5 [115]. So far, dulanermin has been investigated in phase 1 and phase 2 trials for advanced solid 
tumors including colorectal and non-small-cell lung cancer revealing a good safety profile $[116,117]$.

Besides these proapoptotic receptor agonists, other strategies have recently been proposed to enhance the effect of receptor-mediated apoptosis induction. Interference with protein turnover or receptor trafficking, e.g. by application of proteasome inhibitors like bortezomib or protein deacetylase inhibitors, has been shown to increase either death receptor availability or to decrease the availability and function of inhibitory molecules like cellular FLICE-inhibitory protein [118-122].

\section{Mitochondrial Pathway}

To activate the mitochondria-driven apoptosis, inhibitors of Bcl-2 function and $\mathrm{BH} 3$ mimetics have been designed $[123,124]$. One of the first approaches was the antisense-based inhibition of Bcl-2 expression using the DNA antisense oligonucleotide oblimersen (G3139, genasense) [125]. In several clinical trials this strategy proved to lower the apoptotic thresholds in various models and increased the sensitivity towards other chemotherapeutic agents [126-130]. Although results from these trials are promising, approval of this drug is still pending, and additional effects like stimulating Toll-like receptors by CpG motifs contained in the oblimersen sequence are discussed but not fully understood [131]. Recently, the use of short interfering RNA molecules (siRNAs) has been shown to be more powerful in suppressing the expression of target genes. Consequently, several approaches have been made to target antiapoptotic molecules like Bcl-2 with this technique [132]. Although preclinical findings demonstrated a good efficacy in silencing Bcl-2 and thus shifting the apoptotic threshold [133,134], the clinical applicability of siRNA-based therapies is still limited due to unsolved pharmacological problems such as drug delivery or drug targeting issues and the low in vivo stability of siRNA molecules.

Several small molecule inhibitors targeting the antiapoptotic Bcl-2 family members have been investigated recently. These so-called $\mathrm{BH} 3$ mimetics directly interfere with the protein structure of $\mathrm{Bcl}-2, \mathrm{Bcl}-\mathrm{xL}, \mathrm{Bcl}-\mathrm{w}$ or Mcl-1 and thus inhibit the antiapoptotic function of these molecules [124]. Among them, the preclinically most intensively studied compound obatoclax (GX15070) [135-137] and gossypol (AT-101) [138-140] showed very promising results and are currently undergoing clinical testing. ABT-737 and its orally available derivative navitoclax (ABT-263) bind to Bcl-2, Bcl-xL and Bcl-w and sequester proapoptotic $\mathrm{BH} 3$ domain proteins, which promotes the oligomerization of proapoptotic Bax and
Bak [141]. Navitoclax showed a good safety profile in phase 1 trials $[142,143]$ and demonstrated synergistic effects with other chemotherapeutics in various cancer models [144-146].

\section{ER Stressors and UPR Inducers}

Although ER stress and the UPR are themselves potent inducers of noncanonical apoptosis signaling, no specific agents activating this pathway are yet available. Several established compounds interfering with protein metabolism and turnover can induce UPR activation. Here, proteasome inhibitors like brotezomib [147], heat shock protein inhibitors like geldanamycin (17-AAG) [148] or protein deacetylase inhibitors like panobinostat [149-151] can rapidly induce ER stress-mediated apoptosis in cancer cells.

\section{Modulators of Autophagy}

As discussed, it is still under debate whether autophagy acts as a defense mechanism against chemotherapy or if it contributes to the execution of cell death programs. Interestingly, several well-established chemotherapeutic agents have recently been demonstrated to interfere with autophagy programs in tumor cells [152]. While inhibitors of survival pathways blocking the PI3K/Akt/mammalian target of rapamycin axis (e.g. BEZ235, AZD8055 or rapamycin analogs) activate the autophagosome formation, maturation and degradation of autophagolysosomes is inhibited by chloroquine and hydroxychloroquine [153]. Depending on the cellular context, both pathways can contribute to cell death in cancer cells. The latter compounds have been investigated in various trials to overcome autophagy-mediated survival and resistance [154-156].

\section{Inhibitors of IAPs and Survivin}

Caspase activity is tightly controlled by IAPs. Mimetics of Smac/DIABLO have demonstrated high efficacy in inhibiting IAP function and sensitize cancer cells to cytotoxic agents [157]. Yet, none of the currently available peptidic or nonpeptidic Smac mimetics has been investigated in clinical trials. Antisense oligonucleotides against the IAP inducer survivin (LY2181308) or against XIAP (AEG35156) have also shown good tolerability in phase 1 trials [158-160] but need to be confirmed in larger patient cohorts [161]. 


\section{Conclusion}

The growing understanding of the complexity of cell death programs has opened new possibilities to exploit these pathways for targeted cancer therapies. Although most of the described compounds and agents are still in preclinical or early clinical evaluation and evidencebased data on efficacy and potency are not yet available, the prospect of combining specific apoptosis modulators or inducers with established chemotherapeutic agents will dramatically change our view on cancer chemotherapy. As these modulators span the whole range from monoclonal antibodies targeting death receptors to mod- ulators of intracellular signaling cascades or protein turnover, multiple new studies and study designs need to be conducted and validated to help improving patient care and overall survival of cancer patients. Four decades after the declaration of war on cancer, the war is still not won, but these new weapons can help turn the page for the benefit of numerous patients.

\section{Acknowledgement}

Michael Höpfner was supported by the Schüchtermann-Stiftung, Germany.

\section{References}

$>1$ Kerr JF, Wyllie AH, Currie AR: Apoptosis: a basic biological phenomenon with wideranging implications in tissue kinetics. Br J Cancer 1972;26:239-257.

$\checkmark 2$ Hanahan D, Weinberg RA: Hallmarks of cancer: the next generation. Cell 2011;144: 646-674.

$>3$ Gieseler F, Rudolph P, Kloeppel G, Foelsch UR: Resistance mechanisms of gastrointestinal cancers: why does conventional chemotherapy fail? Int J Colorectal Dis 2003;18: 470-480.

4 Longley DB, Johnston PG: Molecular mechanisms of drug resistance. J Pathol 2005;205: 275-292.

5 Coppin C, Kollmannsberger C, Le L, Porzsolt F, Wilt TJ: Targeted therapy for advanced renal cell cancer (RCC): a Cochrane systematic review of published randomised trials. BJU Int 2011;108:1556-1563.

6 Garrett CR, Eng C: Cetuximab in the treatment of patients with colorectal cancer. Expert Opin Biol Ther 2011;11:937-949.

7 Llovet JM, Ricci S, Mazzaferro V, Hilgard P, Gane E, Blanc JF, de Oliveira AC, Santoro A, Raoul JL, Forner A, Schwartz M, Porta C, Zeuzem S, Bolondi L, Greten TF, Galle PR, Seitz JF, Borbath I, Haussinger D, Giannaris T, Shan M, Moscovici M, Voliotis D, Bruix J: Sorafenib in advanced hepatocellular carcinoma. N Engl J Med 2008;359:378-390.

-8 Dematteo RP, Ballman KV, Antonescu CR, Maki RG, Pisters PW, Demetri GD, Blackstein ME, Blanke CD, von Mehren M, Brennan MF, Patel S, McCarter MD, Polikoff JA, Tan BR, Owzar K: Adjuvant imatinib mesylate after resection of localised, primary gastrointestinal stromal tumour: a randomised, double-blind, placebo-controlled trial. Lancet 2009;373:1097-1104. $\checkmark 9$ Yao JC, Shah MH, Ito T, Bohas CL, Wolin EM, Van Cutsem E, Hobday TJ, Okusaka T, Capdevila J, de Vries EG, Tomassetti P, Pavel ME, Hoosen S, Haas T, Lincy J, Lebwohl D, Oberg K: Everolimus for advanced pancre atic neuroendocrine tumors. N Engl J Med 2011;364:514-523.

10 Platini F, Perez-Tomas R, Ambrosio S, Tessitore L: Understanding autophagy in cell death control. Curr Pharm Des 2010;16:101113.

11 Amaravadi RK, Thompson CB: The roles of therapy-induced autophagy and necrosis in cancer treatment. Clin Cancer Res 2007;13: 7271-7279.

12 Yang Z, Klionsky DJ: Eaten alive: a history of macroautophagy. Nat Cell Biol 2010;12:814822 .

13 Galluzzi L, Kroemer G: Necroptosis: a specialized pathway of programmed necrosis Cell 2008;135:1161-1163.

14 Vakifahmetoglu H, Olsson M, Zhivotovsky B: Death through a tragedy: mitotic catastrophe. Cell Death Differ 2008;15:1153-1162.

15 Castedo M, Perfettini JL, Roumier T, Andreau K, Medema R, Kroemer G: Cell death by mitotic catastrophe: a molecular definition. Oncogene 2004;23:2825-2837.

16 Gupta S: Molecular steps of death receptor and mitochondrial pathways of apoptosis Life Sci 2001;69:2957-2964.

17 Jin Z, El-Deiry WS: Overview of cell death signaling pathways. Cancer Biol Ther 2005; 4:139-163.

18 Savill J, Fadok V: Corpse clearance defines the meaning of cell death. Nature 2000;407: 784-788

19 Wajant H, Pfizenmaier K, Scheurich P: Tumor necrosis factor signaling. Cell Death Differ 2003; 10:45-65.

20 Baud V, Karin M: Signal transduction by tumor necrosis factor and its relatives. Trends Cell Biol 2001;11:372-377.
21 Sayers TJ: Targeting the extrinsic apoptosis signaling pathway for cancer therapy. Cancer Immunol Immunother 2011;60:11731180.

22 Peter ME, Krammer PH: The CD95(Apo-1/ Fas) disc and beyond. Cell Death Differ 2003; 10:26-35.

23 Irmler M, Thome M, Hahne M, Schneider P, Hofmann K, Steiner V, Bodmer JL, Schroter M, Burns K, Mattmann C, Rimoldi D, French LE, Tschopp J: Inhibition of death receptor signals by cellular flip. Nature 1997;388:190 195.

-24 Ashkenazi A, Herbst RS: To kill a tumor cell: the potential of proapoptotic receptor agonists. J Clin Invest 2008;118:1979-1990.

25 Cory S, Adams JM: The Bcl2 family: regulators of the cellular life-or-death switch. Nat Rev Cancer 2002;2:647-656.

26 Giam M, Huang DC, Bouillet P: BH3-only proteins and their roles in programmed cell death. Oncogene 2008;27(suppl 1):S128S136.

27 Zamzami N, Kroemer G: The mitochondrion in apoptosis: how Pandora's box opens. Nat Rev Mol Cell Biol 2001;2:67-71.

28 Green DR, Kroemer G: The pathophysiology of mitochondrial cell death. Science 2004 305:626-629.

29 Liu X, Kim CN, Yang J, Jemmerson R, Wang $\mathrm{X}$ : Induction of apoptotic program in cellfree extracts: requirement for DATP and cytochrome c. Cell 1996;86:147-157.

30 Goldstein JC, Waterhouse NJ, Juin P, Evan GI, Green DR: The coordinate release of cytochrome $\mathrm{c}$ during apoptosis is rapid, complete and kinetically invariant. Nat Cell Biol 2000;2:156-162.

31 Zou H, Henzel WJ, Liu X, Lutschg A, Wang $\mathrm{X}$ : Apaf-1, a human protein homologous to C. elegans ced-4, participates in cytochrome c-dependent activation of caspase-3. Cell 1997;90:405-413. 
- 32 Li P, Nijhawan D, Budihardjo I, Srinivasula SM, Ahmad M, Alnemri ES, Wang X: Cytochrome $c$ and DATP-dependent formation of Apaf-1/caspase-9 complex initiates an apoptotic protease cascade. Cell 1997;91:479489.

- 33 Yuan S, Yu X, Topf M, Ludtke SJ, Wang X, Akey CW: Structure of an apoptosome-procaspase-9 card complex. Structure 2010;18: 571-583.

-34 Scorrano L, Oakes SA, Opferman JT, Cheng EH, Sorcinelli MD, Pozzan T, Korsmeyer SJ: Bax and Bak regulation of endoplasmic reticulum $\mathrm{Ca}^{2+}$ : a control point for apoptosis. Science 2003;300:135-139.

- 35 Elyaman W, Terro F, Suen KC, Yardin C, Chang RC, Hugon J: Bad and Bcl-2 regulation are early events linking neuronal endoplasmic reticulum stress to mitochondriamediated apoptosis. Brain Res Mol Brain Res 2002; 109:233-238.

- 36 Ferri KF, Kroemer G: Organelle-specific initiation of cell death pathways. Nat Cell Biol 2001;3:E255-E263.

- 37 Rodriguez D, Rojas-Rivera D, Hetz C: Integrating stress signals at the endoplasmic reticulum: the Bcl-2 protein family rheostat. Biochim Biophys Acta 2011;1813:564-574.

38 Zhivotovsky B, Orrenius S: Calcium and cell death mechanisms: a perspective from the cell death community. Cell Calcium 2011;50: 211-221.

-39 Walter P, Ron D: The unfolded protein response: from stress pathway to homeostatic regulation. Science 2011;334:1081-1086.

-40 Haze K, Yoshida H, Yanagi H, Yura T, Mori $\mathrm{K}$ : Mammalian transcription factor ATF6 is synthesized as a transmembrane protein and activated by proteolysis in response to endoplasmic reticulum stress. Mol Biol Cell 1999; 10:3787-3799.

-41 Shen J, Chen X, Hendershot L, Prywes R: ER stress regulation of ATF6 localization by dissociation of BIP/GRP78 binding and unmasking of Golgi localization signals. Dev Cell 2002;3:99-111.

42 Ron D, Walter P: Signal integration in the endoplasmic reticulum unfolded protein response. Nat Rev Mol Cell Biol 2007;8:519529.

-43 Nakagawa T, Zhu H, Morishima N, Li E, Xu J, Yankner BA, Yuan J: Caspase-12 mediates endoplasmic-reticulum-specific apoptosis and cytotoxicity by amyloid-beta. Nature 2000;403:98-103.

-44 Harding HP, Zhang Y, Bertolotti A, Zeng H, Ron D: Perk is essential for translational regulation and cell survival during the unfolded protein response. Mol Cell 2000;5:897-904.

45 Urano F, Wang X, Bertolotti A, Zhang Y, Chung P, Harding HP, Ron D: Coupling of stress in the ER to activation of JNK protein kinases by transmembrane protein kinase IRE1. Science 2000;287:664-666.
46 Park HH, Lo YC, Lin SC, Wang L, Yang JK, $\mathrm{Wu} \mathrm{H}$ : The death domain superfamily in intracellular signaling of apoptosis and inflammation. Annu Rev Immunol 2007;25: 561-586.

47 Slee EA, Adrain C, Martin SJ: Serial killers: ordering caspase activation events in apoptosis. Cell Death Differ 1999;6:1067-1074.

48 Degterev A, Boyce M, Yuan J: A decade of caspases. Oncogene 2003;22:8543-8567.

49 Li H, Zhu H, Xu CJ, Yuan J: Cleavage of BID by caspase 8 mediates the mitochondrial damage in the Fas pathway of apoptosis. Cell 1998;94:491-501.

50 Gross A, Yin XM, Wang K, Wei MC, Jockel J, Milliman C, Erdjument-Bromage $\mathrm{H}$, Tempst P, Korsmeyer SJ: Caspase cleaved BID targets mitochondria and is required for cytochrome c release, while BCL-XL prevents this release but not tumor necrosis factor-R1/Fas death. J Biol Chem 1999;274:1156-1163.

$51 \mathrm{Ku}$ NO, Liao J, Omary MB: Apoptosis generates stable fragments of human type I keratins. J Biol Chem 1997;272:33197-33203.

52 Caulin C, Salvesen GS, Oshima RG: Caspase cleavage of keratin 18 and reorganization of intermediate filaments during epithelial cell apoptosis. J Cell Biol 1997;138:1379-1394.

53 Coleman ML, Sahai EA, Yeo M, Bosch M, Dewar A, Olson MF: Membrane blebbing during apoptosis results from caspase-mediated activation of ROCK I. Nat Cell Biol 2001; 3:339-345

54 Janicke RU, Walker PA, Lin XY, Porter AG: Specific cleavage of the retinoblastoma protein by an ICE-like protease in apoptosis. EMBO J 1996;15:6969-6978.

55 Levkau B, Koyama H, Raines EW, Clurman BE, Herren B, Orth K, Roberts JM, Ross R: Cleavage of p21CIP1/WAF1 and p27KIP1 mediates apoptosis in endothelial cells through activation of CDK2: role of a caspase cascade. Mol Cell 1998;1:553-563.

56 Tang D, Kidd VJ: Cleavage of DFF-45/ICAD by multiple caspases is essential for its function during apoptosis. J Biol Chem 1998;273: 28549-28552.

57 Sakahira H, Enari M, Nagata S: Cleavage of CAD inhibitor in CAD activation and DNA degradation during apoptosis. Nature 1998; 391:96-99.

58 Altieri DC: Survivin and IAP proteins in cell-death mechanisms. Biochem J 2010;430: 199-205.

59 Gyrd-Hansen M, Meier P: IAPs: from caspase inhibitors to modulators of NF-kappaB, inflammation and cancer. Nat Rev Cancer 2010;10:561-574.

60 Wei Y, Fan T, Yu M: Inhibitor of apoptosis proteins and apoptosis. Acta Biochim Biophys Sin (Shanghai) 2008;40:278-288.

61 Deveraux QL, Leo E, Stennicke HR, Welsh K, Salvesen GS, Reed JC: Cleavage of human inhibitor of apoptosis protein XIAP results in fragments with distinct specificities for caspases. ЕMBO J 1999;18:5242-5251.
62 Darding M, Meier P: IAPs: Guardians of RIPK1. Cell Death Differ 2012;19:58-66.

63 Oppenheim RW, Flavell RA, Vinsant S, Prevette $\mathrm{D}$, Kuan CY, Rakic P: Programmed cell death of developing mammalian neurons after genetic deletion of caspases. J Neurosci 2001;21:4752-4760.

64 Edinger AL, Thompson CB: Death by design: apoptosis, necrosis and autophagy. Curr Opin Cell Biol 2004;16:663-669.

65 Hitomi J, Christofferson DE, Ng A, Yao J, Degterev A, Xavier RJ, Yuan J: Identification of a molecular signaling network that regulates a cellular necrotic cell death pathway. Cell 2008;135:1311-1323.

66 Vandenabeele P, Galluzzi L, Vanden Berghe T, Kroemer G: Molecular mechanisms of necroptosis: an ordered cellular explosion. Nat Rev Mol Cell Biol 2010;11:700-714.

67 Degterev A, Huang Z, Boyce M, Li Y, Jagtap P, Mizushima N, Cuny GD, Mitchison TJ Moskowitz MA, Yuan J: Chemical inhibitor of nonapoptotic cell death with therapeutic potential for ischemic brain injury. Nat Chem Biol 2005;1:112-119.

68 Temkin V, Huang Q, Liu H, Osada H, Pope RM: Inhibition of ADP/ATP exchange in receptor-interacting protein-mediated necrosis. Mol Cell Biol 2006;26:2215-2225.

69 Degterev A, Yuan J: Expansion and evolution of cell death programmes. Nat Rev Mol Cell Biol 2008;9:378-390.

-70 Green DR, Oberst A, Dillon CP, Weinlich R, Salvesen GS: RIPK-dependent necrosis and its regulation by caspases: a mystery in five acts. Mol Cell 2011;44:9-16.

71 Oberstein A, Jeffrey PD, Shi Y: Crystal structure of the BCL-XL-beclin 1 peptide complex: beclin 1 is a novel $\mathrm{BH} 3$-only protein. J Biol Chem 2007;282:13123-13132.

72 He C, Klionsky DJ: Regulation mechanisms and signaling pathways of autophagy. Annu Rev Genet 2009;43:67-93.

73 Eskelinen EL: New insights into the mechanisms of macroautophagy in mammalian cells. Int Rev Cell Mol Biol 2008;266:207247.

74 Ullman E, Fan Y, Stawowczyk M, Chen HM, Yue Z, Zong WX: Autophagy promotes necrosis in apoptosis-deficient cells in response to ER stress. Cell Death Differ 2008;15:422425 .

-75 Shimizu S, Kanaseki T, Mizushima N, Mizuta T, Arakawa-Kobayashi S, Thompson CB, Tsujimoto Y: Role of BCL-2 family proteins in a non-apoptotic programmed cell death dependent on autophagy genes. Nat Cell Biol 2004;6:1221-1228.

76 Baehrecke EH: Autophagy: dual roles in life and death? Nat Rev Mol Cell Biol 2005;6: 505-510.

77 Fazi B, Bursch W, Fimia GM, Nardacci R, Piacentini M, Di Sano F, Piredda L: Fenretinide induces autophagic cell death in caspase-defective breast cancer cells. Autophagy $2008 ; 4: 435-441$. 
-78 Simpson CD, Anyiwe K, Schimmer AD: Anoikis resistance and tumor metastasis. Cancer Lett 2008;272:177-185.

-79 Ozden SA, Ozyurt H, Ozgen Z, Kilinc O, Oncel M, Gul AE, Karadayi N, Serakinci N, Kan B, Orun O: Prognostic role of sensitive-toapoptosis gene expression in rectal cancer. World J Gastroenterol 2011;17:4905-4910.

\$80 Chen MK, Lai JC, Chang CC, Chang JH, Chang YJ, Chen HC: Prognostic impact of Bcl-2 expression on advanced nasopharyngeal carcinoma. Head Neck 2008;30:10521057.

81 Callagy GM, Webber MJ, Pharoah PD, Caldas C: Meta-analysis confirms $\mathrm{Bcl} 2$ is an independent prognostic marker in breast cancer. BMC Cancer 2008;8:153.

82 Bria E, Visca P, Novelli F, Casini B, Diodoro MG, Perrone-Donnorso R, Botti C, Sperduti I, Facciolo F, Milella M, Cecere FL, Cognetti F, Mottolese M: Nuclear and cytoplasmic cellular distribution of survivin as survival predictor in resected non-small-cell lung cancer. Eur J Surg Oncol 2008;34:593-598.

-83 Okumura M, Kajiyama Y, Takeda K, Okumura K, Tsurumaru M: Correlation between loss of Bcl-xL expression and improved prognosis in advanced esophageal cancer treated by preoperative chemoradiotherapy. Eur Surg Res 2008;41:260-266.

-84 Nagata M, Nakayama H, Tanaka T, Yoshida R, Yoshitake Y, Fukuma D, Kawahara K, Nakagawa Y, Ota K, Hiraki A, Shinohara M: Overexpression of cIAP2 contributes to 5 -FU resistance and a poor prognosis in oral squamous cell carcinoma. Br J Cancer 2011; 105:1322-1330.

-85 Kim MA, Lee HE, Lee HS, Yang HK, Kim WH: Expression of apoptosis-related proteins and its clinical implication in surgically resected gastric carcinoma. Virchows Arch 2011;459:503-510.

-86 Augello C, Caruso L, Maggioni M, Donadon M, Montorsi M, Santambrogio R, Torzilli G, Vaira V, Pellegrini C, Roncalli M, Coggi G, Bosari S: Inhibitors of apoptosis proteins (IAPs) expression and their prognostic significance in hepatocellular carcinoma. BMC Cancer 2009;9:125.

-87 Kang SY, Han JH, Lee KJ, Choi JH, Park JI, Kim HI, Lee HW, Jang JH, Park JS, Kim HC, Kang S, Oh YT, Chun M, Kim JH, Sheen SS, Lim HY: Low expression of Bax predicts poor prognosis in patients with locally advanced esophageal cancer treated with definitive chemoradiotherapy. Clin Cancer Res 2007;13:4146-4153.

-88 Pluta P, Cebula-Obrzut B, Ehemann V, Pluta A, Wierzbowska A, Piekarski J, Bilski A, Nejc D, Kordek R, Robak T, Smolewski P, Jeziorski A: Correlation of Smac/DIABLO protein expression with the clinico-pathological features of breast cancer patients. Neoplasma 2011;58:430-435.
89 Mizutani Y, Katsuoka Y, Bonavida B: Prognostic significance of second mitochondria-derived activator of caspase (Smac/ DIABLO) expression in bladder cancer and target for therapy. Int J Oncol 2010;37:503508.

-90 Zlobec I, Minoo P, Baker K, Haegert D, Khetani K, Tornillo L, Terracciano L, Jass JR, Lugli A: Loss of Apaf-1 expression is associated with tumour progression and adverse prognosis in colorectal cancer. Eur J Cancer 2007;43:1101-1107.

-91 Anees M, Horak P, El-Gazzar A, Susani M, Heinze G, Perco P, Loda M, Lis R, Krainer $\mathrm{M}$, Oh WK: Recurrence-free survival in prostate cancer is related to increased stromal TRAIL expression. Cancer 2011;117: 1172-1182.

-92 Kriegl L, Jung A, Engel J, Jackstadt R, Gerbes AL, Gallmeier E, Reiche JA, Hermeking H, Rizzani A, Bruns CJ, Kolligs FT, Kirchner T, Goke B, De Toni EN: Expression, cellular distribution, and prognostic relevance of TRAIL receptors in hepatocellular carcinoma. Clin Cancer Res 2010;16:5529-5538.

-93 Martinez R, Setien F, Voelter C, Casado S, Quesada MP, Schackert G, Esteller M: CPG island promoter hypermethylation of the pro-apoptotic gene caspase- 8 is a common hallmark of relapsed glioblastoma multiforme. Carcinogenesis 2007;28:1264-1268.

-94 Datta SR, Dudek H, Tao X, Masters S, Fu H, Gotoh Y, Greenberg ME: Akt phosphorylation of bad couples survival signals to the cell-intrinsic death machinery. Cell 1997; 91:231-241.

95 Cardone MH, Roy N, Stennicke HR, Salvesen GS, Franke TF, Stanbridge E, Frisch S, Reed JC: Regulation of cell death protease caspase- 9 by phosphorylation. Science 1998;282:1318-1321.

96 Brunet A, Bonni A, Zigmond MJ, Lin MZ, Juo P, Hu LS, Anderson MJ, Arden KC, Blenis J, Greenberg ME: Akt promotes cell survival by phosphorylating and inhibiting a forkhead transcription factor. Cell 1999;96: 857-868.

97 Castedo M, Ferri KF, Kroemer G: Mammalian target of rapamycin (mTOR): pro- and anti-apoptotic. Cell Death Differ 2002;9: 99-100.

$\$ 98$ Furuta S, Hidaka E, Ogata A, Yokota S, Kamata T: Ras is involved in the negative control of autophagy through the class I PI3kinase. Oncogene 2004;23:3898-3904.

$\$ 99$ Ravikumar B, Vacher C, Berger Z, Davies JE, Luo S, Oroz LG, Scaravilli F, Easton DF, Duden R, O'Kane CJ, Rubinsztein DC: Inhibition of mTOR induces autophagy and reduces toxicity of polyglutamine expansions in fly and mouse models of Huntington disease. Nat Genet 2004;36:585-595.

100 Wiezorek J, Holland P, Graves J: Death receptor agonists as a targeted therapy for cancer. Clin Cancer Res 2010;16:1701-1708.
01 Kaplan-Lefko PJ, Graves JD, Zoog SJ, Pan Y, Wall J, Branstetter DG, Moriguchi J, Coxon A, Huard JN, Xu R, Peach ML, Juan G, Kaufman S, Chen Q, Bianchi A, Kordich JJ, Ma M, Foltz IN, Gliniak BC: Conatumumab, a fully human agonist antibody to death receptor 5 , induces apoptosis via caspase activation in multiple tumor types. Cancer Biol Ther 2010;9:618-631.

102 Yada A, Yazawa M, Ishida S, Yoshida H, Ichikawa K, Kurakata S, Fujiwara K: A novel humanized anti-human death receptor 5 antibody CS-1008 induces apoptosis in tumor cells without toxicity in hepatocytes. Ann Oncol 2008; 19:1060-1067.

103 Zhang L, Zhang X, Barrisford GW, Olumi AF: Lexatumumab (TRAIL-receptor 2 $\mathrm{mAb}$ ) induces expression of DRr5 and promotes apoptosis in primary and metastatic renal cell carcinoma in a mouse orthotopic model. Cancer Lett 2007;251:146-157.

104 Camidge DR, Herbst RS, Gordon MS, Eckhardt SG, Kurzrock R, Durbin B, Ing J, Tohnya TM, Sager J, Ashkenazi A, Bray G, Mendelson D: A phase I safety and pharmacokinetic study of the death receptor 5 agonistic antibody PRO95780 in patients with advanced malignancies. Clin Cancer Res 2010;16:1256-1263.

105 Doi T, Murakami H, Ohtsu A, Fuse N, Yoshino T, Yamamoto N, Boku N, Onozawa Y, Hsu CP, Gorski KS, Friberg G, Kawaguchi T, Sasaki T: Phase 1 study of conatumumab, a pro-apoptotic death receptor 5 agonist antibody, in Japanese patients with advanced solid tumors. Cancer Chemother Pharmacol 2011;68:733-741.

106 Herbst RS, Kurzrock R, Hong DS, Valdivieso M, Hsu CP, Goyal L, Juan G, Hwang YC, Wong S, Hill JS, Friberg G, LoRusso PM: A first-in-human study of conatumumab in adult patients with advanced solid tumors. Clin Cancer Res 2010;16: 5883-5891.

107 Forero-Torres A, Shah J, Wood T, Posey J, Carlisle R, Copigneaux C, Luo FR, Wojtowicz-Praga S, Percent I, Saleh M: Phase I trial of weekly tigatuzumab, an agonistic humanized monoclonal antibody targeting death receptor 5 (DR5). Cancer Biother Radiopharm 2010;25:13-19.

108 Wakelee HA, Patnaik A, Sikic BI, Mita M, Fox NL, Miceli R, Ullrich SJ, Fisher GA, Tolcher AW: Phase I and pharmacokinetic study of lexatumumab (HGS-ETR2) given every 2 weeks in patients with advanced solid tumors. Ann Oncol 2010;21:376-381.

109 Plummer R, Attard G, Pacey S, Li L, Razak A, Perrett R, Barrett M, Judson I, Kaye S, Fox NL, Halpern W, Corey A, Calvert H, de Bono J: Phase 1 and pharmacokinetic study of lexatumumab in patients with advanced cancers. Clin Cancer Res 2007;13:61876194. 
-110 Tolcher AW, Mita M, Meropol NJ, von Mehren M, Patnaik A, Padavic K, Hill M, Mays T, McCoy T, Fox NL, Halpern W, Corey A, Cohen RB: Phase I pharmacokinetic and biologic correlative study of mapatumumab, a fully human monoclonal antibody with agonist activity to tumor necrosis factor-related apoptosis-inducing ligand receptor-1. J Clin Oncol 2007;25:1390-1395.

- 111 Greco FA, Bonomi P, Crawford J, Kelly K, Oh Y, Halpern W, Lo L, Gallant G, Klein J: Phase 2 study of mapatumumab, a fully human agonistic monoclonal antibody which targets and activates the TRAIL receptor-1, in patients with advanced non-small cell lung cancer. Lung Cancer 2008;61:82-90.

- 112 Hotte SJ, Hirte HW, Chen EX, Siu LL, Le LH, Corey A, Iacobucci A, MacLean M, Lo L, Fox NL, Oza AM: A phase 1 study of mapatumumab (fully human monoclonal antibody to TRAIL-R1) in patients with advanced solid malignancies. Clin Cancer Res 2008; 14:3450-3455.

-113 Leong S, Cohen RB, Gustafson DL, Langer CJ, Camidge DR, Padavic K, Gore L, Smith M, Chow LQ, von Mehren M, O’Bryant C, Hariharan S, Diab S, Fox NL, Miceli R, Eckhardt SG: Mapatumumab, an antibody targeting TRAIL-R1, in combination with paclitaxel and carboplatin in patients with advanced solid malignancies: Results of a phase I and pharmacokinetic study. J Clin Oncol 2009;27:4413-4421.

- 114 Trarbach T, Moehler M, Heinemann V, Kohne CH, Przyborek M, Schulz C, Sneller V, Gallant G, Kanzler S: Phase II trial of mapatumumab, a fully human agonistic monoclonal antibody that targets and activates the tumour necrosis factor apoptosisinducing ligand receptor-1 (TRAIL-R1), in patients with refractory colorectal cancer. Br J Cancer 2010;102:506-512.

-115 Ashkenazi A, Pai RC, Fong S, Leung S, Lawrence DA, Marsters SA, Blackie C, Chang L, McMurtrey AE, Hebert A, DeForge L, Koumenis IL, Lewis D, Harris L, Bussiere J, Koeppen H, Shahrokh Z, Schwall RH: Safety and antitumor activity of recombinant soluble Apo2 ligand. J Clin Invest 1999;104: 155-162.

- 116 Herbst RS, Eckhardt SG, Kurzrock R, Ebbinghaus S, O'Dwyer PJ, Gordon MS, Novotny W, Goldwasser MA, Tohnya TM, Lum BL, Ashkenazi A, Jubb AM, Mendelson DS: Phase I dose-escalation study of recombinant human Apo2L/TRAIL, a dual proapoptotic receptor agonist, in patients with advanced cancer. J Clin Oncol 2010; 28:2839-2846.

- 117 Soria JC, Mark Z, Zatloukal P, Szima B, Albert I, Juhasz E, Pujol JL, Kozielski J, Baker N, Smethurst D, Hei YJ, Ashkenazi A, Stern H, Amler L, Pan Y, Blackhall F: Randomized phase II study of dulanermin in combination with paclitaxel, carboplatin, and bevacizumab in advanced non-small-cell lung cancer. J Clin Oncol 2011;29:4442-4451.
8 Liu X, Yue P, Chen S, Hu L, Lonial S, Khuri FR, Sun SY: The proteasome inhibitor PS341 (bortezomib) up-regulates DR5 expression leading to induction of apoptosis and enhancement of TRAIL-induced apoptosis despite up-regulation of c-FLIP and survivin expression in human NSCLC cells. Cancer Res 2007;67:4981-4988.

119 Thorpe JA, Christian PA, Schwarze SR: Proteasome inhibition blocks caspase- 8 degradation and sensitizes prostate cancer cells to death receptor-mediated apoptosis. Prostate 2008;68:200-209.

120 Kandasamy K, Kraft AS: Proteasome inhibitor PS-341 (Velcade) induces stabilization of the TRAIL receptor DR5 mRNA through the 3 '-untranslated region. Mol Cancer Ther 2008;7:1091-1100.

121 Wood TE, Dalili S, Simpson CD, Sukhai MA, Hurren R, Anyiwe K, Mao X, Suarez Saiz F, Gronda M, Eberhard Y, MacLean N, Ketela T, Reed JC, Moffat J, Minden MD, Batey RA, Schimmer AD: Selective inhibition of histone deacetylases sensitizes malignant cells to death receptor ligands. Mol Cancer Ther 2010;9:246-256.

122 Schuchmann M, Schulze-Bergkamen H, Fleischer B, Schattenberg JM, Siebler J, Weinmann A, Teufel A, Worns M, Fischer T, Strand S, Lohse AW, Galle PR: Histone deacetylase inhibition by valproic acid down-regulates c-FLIP/CASH and sensitizes hepatoma cells towards CD95- and trail receptor-mediated apoptosis and chemotherapy. Oncol Rep 2006;15:227-230.

123 Chonghaile TN, Letai A: Mimicking the $\mathrm{BH} 3$ domain to kill cancer cells. Oncogene 2008;27(suppl 1):S149-S157.

124 Kang MH, Reynolds CP: Bcl-2 inhibitors: targeting mitochondrial apoptotic pathways in cancer therapy. Clin Cancer Res 2009;15:1126-1132.

125 Raynaud FI, Orr RM, Goddard PM, Lacey HA, Lancashire H, Judson IR, Beck T, Bryan B, Cotter FE: Pharmacokinetics of G3139, a phosphorothioate oligodeoxynucleotide antisense to $\mathrm{Bcl}-2$, after intravenous administration or continuous subcutaneous infusion to mice. J Pharmacol Exp Ther 1997;281:420-427.

126 Lopes de Menezes DE, Hudon N, McIntosh N, Mayer LD: Molecular and pharmacokinetic properties associated with the therapeutics of Bcl-2 antisense oligonucleotide G3139 combined with free and liposomal doxorubicin. Clin Cancer Res 2000;6:28912902.

127 Jansen B, Wacheck V, Heere-Ress E, Schlagbauer-Wadl H, Hoeller C, Lucas T, Hoermann M, Hollenstein U, Wolff K, Pehamberger $\mathrm{H}$ : Chemosensitisation of malignant melanoma by $\mathrm{Bcl} 2$ antisense therapy. Lancet 2000;356:1728-1733.
128 Tolcher AW: Preliminary phase I results of G3139 (Bcl-2 antisense oligonucleotide) therapy in combination with docetaxel in hormone-refractory prostate cancer. Semin Oncol 2001;28:67-70.

129 O’Brien S, Moore JO, Boyd TE, Larratt LM, Skotnicki A, Koziner B, Chanan-Khan AA, Seymour JF, Bociek RG, Pavletic S, Rai KR: Randomized phase III trial of fludarabine plus cyclophosphamide with or without oblimersen sodium (Bcl-2 antisense) in patients with relapsed or refractory chronic lymphocytic leukemia. J Clin Oncol 2007; 25:1114-1120.

130 O'Brien S, Moore JO, Boyd TE, Larratt LM, Skotnicki AB, Koziner B, Chanan-Khan AA, Seymour JF, Gribben J, Itri LM, Rai KR: 5-year survival in patients with relapsed or refractory chronic lymphocytic leukemia in a randomized, phase III trial of fludarabine plus cyclophosphamide with or without oblimersen. J Clin Oncol 2009;27: 5208-5212.

131 Jahrsdorfer B, Jox R, Muhlenhoff L, Tschoep K, Krug A, Rothenfusser S, Meinhardt G, Emmerich B, Endres S, Hartmann G: Modulation of malignant $B$ cell activation and apoptosis by Bcl-2 antisense ODN and immunostimulatory CPG ODN. J Leukoc Biol 2002;72:83-92.

132 Okamoto K, Murawaki Y: The therapeutic potential of RNA interference: novel approaches for cancer treatment. Curr Pharm Biotechnol 2011, E-pub ahead of print.

133 Ocker M, Neureiter D, Lueders M, Zopf S, Ganslmayer M, Hahn EG, Herold C, Schuppan D: Variants of Bcl-2 specific siRNA for silencing antiapoptotic Bcl-2 in pancreatic cancer. Gut 2005;54:1298-1308.

134 Okamoto K, Ocker M, Neureiter D, Dietze O, Zopf S, Hahn EG, Herold C: Bcl-2-specific siRNAs restore gemcitabine sensitivity in human pancreatic cancer cells. J Cell Mol Med 2007;11:349-361.

135 Hwang JJ, Kuruvilla J, Mendelson D, Pishvaian MJ, Deeken JF, Siu LL, Berger MS, Viallet J, Marshall JL: Phase I dose finding studies of obatoclax (GX15-070), a small molecule pan-Bcl-2 family antagonist, in patients with advanced solid tumors or lymphoma. Clin Cancer Res 2010;16:40384045.

136 Paik PK, Rudin CM, Pietanza MC, Brown A, Rizvi NA, Takebe N, Travis W, James L, Ginsberg MS, Juergens R, Markus S, Tyson L, Subzwari S, Kris MG, Krug LM: A phase II study of obatoclax mesylate, a Bcl-2 antagonist, plus topotecan in relapsed small cell lung cancer. Lung Cancer 2011;74:481-485.

137 Paik PK, Rudin CM, Brown A, Rizvi NA, Takebe N, Travis W, James L, Ginsberg MS, Juergens R, Markus S, Tyson L, Subzwari S, Kris MG, Krug LM: A phase I study of obatoclax mesylate, a Bcl-2 antagonist, plus topotecan in solid tumor malignancies. Cancer Chemother Pharmacol 2010;66: 1079-1085. 
138 Van Poznak C, Seidman AD, Reidenberg MM, Moasser MM, Sklarin N, Van Zee K, Borgen P, Gollub M, Bacotti D, Yao TJ, Bloch R, Ligueros M, Sonenberg M, Norton L, Hudis C: Oral gossypol in the treatment of patients with refractory metastatic breast cancer: a phase I/II clinical trial. Breast Cancer Res Treat 2001;66:239-248.

-139 Heist RS, Fain J, Chinnasami B, Khan W, Molina JR, Sequist LV, Temel JS, Fidias P, Brainerd V, Leopold L, Lynch TJ: Phase I/II study of AT-101 with topotecan in relapsed and refractory small cell lung cancer. J Thorac Oncol 2010;5:1637-1643.

140 Ready N, Karaseva NA, Orlov SV, Luft AV, Popovych O, Holmlund JT, Wood BA, Leopold L: Double-blind, placebo-controlled, randomized phase 2 study of the proapoptotic agent AT-101 plus docetaxel, in second-line non-small cell lung cancer. J Thorac Oncol 2011;6:781-785.

141 Oltersdorf T, Elmore SW, Shoemaker AR, Armstrong RC, Augeri DJ, Belli BA, Bruncko M, Deckwerth TL, Dinges J, Hajduk PJ, Joseph MK, Kitada S, Korsmeyer SJ, Kunzer AR, Letai A, Li C, Mitten MJ, Nettesheim DG, Ng S, Nimmer PM, O'Connor JM, Oleksijew A, Petros AM, Reed JC, Shen W, Tahir SK, Thompson CB, Tomaselli KJ, Wang B, Wendt MD, Zhang H, Fesik SW, Rosenberg SH: An inhibitor of Bcl-2 family proteins induces regression of solid tumours. Nature 2005;435:677-681.

142 Gandhi L, Camidge DR, Ribeiro de Oliveira $\mathrm{M}$, Bonomi $\mathrm{P}$, Gandara D, Khaira D, Hann CL, McKeegan EM, Litvinovich E, Hemken PM, Dive C, Enschede SH, Nolan C, Chiu YL, Busman T, Xiong H, Krivoshik AP, Humerickhouse R, Shapiro GI, Rudin CM: Phase I study of navitoclax (ABT-263), a novel Bcl-2 family inhibitor, in patients with small-cell lung cancer and other solid tumors. J Clin Oncol 2011;29:909-916.

143 Wilson WH, O'Connor OA, Czuczman MS, LaCasce AS, Gerecitano JF, Leonard JP, Tulpule A, Dunleavy K, Xiong H, Chiu YL, Cui Y, Busman T, Elmore SW, Rosenberg SH, Krivoshik AP, Enschede SH, Humerickhouse RA: Navitoclax, a targeted highaffinity inhibitor of Bcl-2, in lymphoid malignancies: a phase 1 dose-escalation study of safety, pharmacokinetics, pharmacodynamics, and antitumour activity. Lancet Oncol 2010;11:1149-1159.
144 Tan N, Malek M, Zha J, Yue P, Kassees R, Berry L, Fairbrother WJ, Sampath D, Belmont LD: Navitoclax enhances the efficacy of taxanes in non-small cell lung cancer models. Clin Cancer Res 2011;17:13941404.

145 Wang G, Zhan Y, Wang H, Li W: ABT-263 sensitizes TRAIL-resistant hepatocarcinoma cells by downregulating the $\mathrm{Bcl}-2 \mathrm{fam}$ ily of anti-apoptotic protein. Cancer Chemother Pharmacol 2011, E-pub ahead of print.

146 Chen J, Jin S, Abraham V, Huang X, Liu B, Mitten MJ, Nimmer P, Lin X, Smith M, Shen Y, Shoemaker AR, Tahir SK, Zhang H, Ackler SL, Rosenberg SH, Maecker H, Sampath $\mathrm{D}$, Leverson JD, Tse C, Elmore SW: The Bcl-2/Bcl-xL/Bcl-w inhibitor, navitoclax, enhances the activity of chemotherapeutic agents in vitro and in vivo. Mol Cancer Ther 2011;10:2340-2349.

147 Nawrocki ST, Carew JS, Dunner K Jr, Boise LH, Chiao PJ, Huang P, Abbruzzese JL, McConkey DJ: Bortezomib inhibits PKR-like endoplasmic reticulum (ER) kinase and induces apoptosis via ER stress in human pancreatic cancer cells. Cancer Res 2005; 65:11510-11519.

148 Taiyab A, Sreedhar AS, Rao ChM: Hsp90 inhibitors, GA and 17AAG, lead to ER stress-induced apoptosis in rat histiocytoma. Biochem Pharmacol 2009;78:142-152.

149 Di Fazio P, Ocker M, Montalbano R: New drugs, old fashioned ways: ER stress induced cell death. Curr Pharm Biotechnol 2011, E-pub ahead of print.

150 Di Fazio P, Schneider-Stock R, Neureiter D, Okamoto K, Wissniowski T, Gahr S, Quint $\mathrm{K}$, Meissnitzer M, Alinger B, Montalbano R, Sass G, Hohenstein B, Hahn EG, Ocker $\mathrm{M}$ : The pan-deacetylase inhibitor panobinostat inhibits growth of hepatocellular carcinoma models by alternative pathways of apoptosis. Cell Oncol 2010;32:285-300.

151 Ocker M: Deacetylase inhibitors - focus on non-histone targets and effects. World J Biol Chem 2010;1:55-61.

152 Apel A, Zentgraf H, Buchler MW, Herr I: Autophagy - a double-edged sword in oncology. Int J Cancer 2009;125:991-995.

153 Yang ZJ, Chee CE, Huang S, Sinicrope FA: The role of autophagy in cancer: therapeutic implications. Mol Cancer Ther 2011;10: 1533-1541.
154 Han W, Sun J, Feng L, Wang K, Li D, Pan Q, Chen Y, Jin W, Wang X, Pan H, Jin H: Autophagy inhibition enhances daunorubicin-induced apoptosis in K562 cells. PLoS One 2011;6:e28491.

-155 Shi YH, Ding ZB, Zhou J, Hui B, Shi GM, Ke AW, Wang XY, Dai Z, Peng YF, Gu CY, Qiu SJ, Fan J: Targeting autophagy enhances sorafenib lethality for hepatocellular carcinoma via ER stress-related apoptosis. Autophagy 2011;7:1159-1172.

156 Sasaki K, Tsuno NH, Sunami E, Tsurita G, Kawai K, Okaji Y, Nishikawa T, Shuno Y, Hongo K, Hiyoshi M, Kaneko M, Kitayama J, Takahashi K, Nagawa H: Chloroquine potentiates the anti-cancer effect of 5-fluorouracil on colon cancer cells. BMC Cancer 2010;10:370.

157 Chen DJ, Huerta S: Smac mimetics as new cancer therapeutics. Anticancer Drugs 2009;20:646-658.

158 Tanioka M, Nokihara H, Yamamoto N, Yamada Y, Yamada K, Goto Y, Fujimoto T, Sekiguchi R, Uenaka K, Callies S, Tamura T: Phase I study of LY2181308, an antisense oligonucleotide against survivin, in patients with advanced solid tumors. Cancer Chemother Pharmacol 2011;68:505-511.

159 Talbot DC, Ranson M, Davies J, Lahn M, Callies S, Andre V, Kadam S, Burgess M, Slapak C, Olsen AL, McHugh PJ, de Bono JS, Matthews J, Saleem A, Price P: Tumor survivin is downregulated by the antisense oligonucleotide LY2181308: a proof-of-concept, first-in-human dose study. Clin Cancer Res 2010;16:6150-6158.

160 Schimmer AD, Estey EH, Borthakur G, Carter BZ, Schiller GJ, Tallman MS, Altman JK, Karp JE, Kassis J, Hedley DW, Brandwein J, Xu W, Mak DH, LaCasse E, Jacob C, Morris SJ, Jolivet J, Andreeff M: Phase I/II trial of AEG35156 X-linked inhibitor of apoptosis protein antisense oligonucleotide combined with idarubicin and cytarabine in patients with relapsed or primary refractory acute myeloid leukemia. J Clin Oncol 2009;27:4741-4746.

161 Kelly RJ, Lopez-Chavez A, Citrin D, Janik JE, Morris JC: Impacting tumor cell-fate by targeting the inhibitor of apoptosis protein survivin. Mol Cancer 2011;10:35. 